\title{
Pengaruh Literasi Keuangan dan Gaya Hidup Terhadap Pengelolaan Keuangan Karyawan (Studi di PT. Mulia Boga Raya Tbk)
}

\author{
Lia Putri Utami ${ }^{1}$, Netti Natarida Marpaung ${ }^{2}$ \\ Mahasiswa Program Studi Manajemen ${ }^{1}$ \\ Dosen Sekolah Tinggi Ilmu Ekonomi Tribuana ${ }^{2}$ \\ liaputri301099@gmail.com
}

\begin{abstract}
Financial management can help every individual in managing finances. Regulating and managing what is meant is that someone can allocate their income for various things, including consumption, educational needs, and savings. Lifestyle affects how individuals view financial management and how they set the rules for managing finances. This study aims to examine the relationship between financial literacy and lifestyle on the financial management of employees and to determine the differences in financial literacy, lifestyle and financial management of employees of PT. Mulia Boga Raya Tbk. This research is a quantitative research with data collection techniques using a questionnaire. The sample used is 42 employees of PT. Mulia Boga Raya Tbk who works in the Office. The analysis technique used is multiple linear regression analysis which is used to determine the effect of the independent variable and the dependent variable. Data analysis includes normality test, heteroscedasticity test, multicollinearity test, multiple regression analysis, $t$ test, $f$ test and determinant coefficient test (R2). The results of this study are financial literacy variables affect the financial management of employees of PT. Mulia Boga Raya Tbk who works in the Office. While the lifestyle variables have no effect on the financial management of PT. Mulia Boga Raya Tbk who works in the Office.
\end{abstract}

Keywords: Financial Literacy, Lifestyle, Employee Financial Management

\begin{abstract}
Abstrak
Pengelolaan keuangan dapat membantu setiap individu dalam mengatur keuangan. Mengatur dan mengelola yang dimaksud adalah seseorang dapat mengalokasikan pendapatan yang dimiliki untuk berbagai hal, diantaranya untuk konsumsi, kebutuhan pendidikan, dan simpanan. Gaya hidup mempengaruhi bagaimana individu memandang pengelolaan keuangan dan bagaimana mereka menetapkan aturan mengelola keuangan. Penelitian ini bertujuan untuk meneliti hubungan antara literasi keuangan dan gaya hidup terhadap pengelolaan keuangan karyawan dan mengetahui perbedaan literasi keuangan, gaya hidup dan pengelolaan keuangan karyawan PT. Mulia Boga Raya Tbk. Penelitian ini adalah penelitian kuantitatif dengan teknik pengumpulan data menggunakan kuesioner. Sample yang digunakan berjumlah 42 karyawan PT. Mulia Boga Raya Tbk yang bekerja di Office. Teknik analisis yang digunakan adalah analisis regresi linier berganda yang digunakan untuk mengetahui pengaruh variabel bebas dengan variabel terikat. Analisis data meliputi uji normalitas, uji heterokedasitas,uji multikolinearitas, analisis regresi berganda, uji $t$, uji $f$ dan uji koefisien determinan (R2). Hasil penelitian ini adalah variabel literasi keuangan berpengaruh terhadap pengelolaan keuangan karyawan PT. Mulia Boga Raya Tbk yang bekerja di Office. Sedangkan variabel gaya hidup tidak berpengaruh terhadap pengelolaan keuangan karyawan PT. Mulia Boga Raya Tbk yang bekerja di Office.

Kata kunci: Literasi Keuangan, Gaya Hidup, Pengelolaan Keuangan Karyawan
\end{abstract}




\section{PENDAHULUAN}

Berkembangnya pengelolaan keuangan dipelopori oleh adanya adanya perilaku seseorang dalam proses pengambilan keputusan. Pengelolaan keuangan haruslah mengarah pada perilaku keuangan yang bertanggung jawab sehingga seluruh keuangan baik individu maupun keluarga dapat dikelola dengan baik.

Berdasarkan data Badan Pusat Statistik (BPS), pendapatan per kapita masyarakat Indonesia naik dari $\mathrm{Rp}$ 51.900.000,- per kapita per tahun pada tahun 2017 menjadi Rp 56.000.000,- per kapita per tahun pada tahun 2018. Meskipun pendapatan perkapita naik, namun kesejahteraan masyakat miskin belum menunjukan kondisi yang membaik.

Perencanaan keuangan yang dilakukan sejak dini akan membantu seseorang untuk merealisasikan tujuan hidupnya. Seorang karyawan yang menghasilkan sejumlah uang atau memperoleh pendapatan, sepatutnya harus mengetahui kemana setiap rupiah dari pendapatannya tersebut ditempatkan. Pengaturan kemana saja penempatan uang yang diperoleh harus diperhitungkan dalam sebuah perencanaan keuangan sehingga berbagai tujuan dapat tercapai dengan baik di masa mendatang.
Melakukan perencanaan keuangan yang baik, membuat seseorang dapat mengantisipasi risiko keuangan yang akan terjadi.

Literasi keuangan erat kaitannya dengan manajemen keuangan dimana semakin tinggi tingkat literasi keuangan seseorang maka semakin baik pula manajemen keuangan seseorang tersebut. Manajemen keuangan pribadi merupakan salah satu aplikasi dari konsep manajemen keuangan pada level individu.

Manajemen keuangan yang meliputi aktivitas perencanaan, pengelolaan dan pengendalian keuangan, sangatlah penting untuk mencapai kesejahteraan finansial. Aktivitas perencanaan meliputi kegiatan untuk merencanakan alokasi pendapatan yang diperoleh akan digunakan untuk apa saja.

Pengelolaan merupakan kegiatan untuk mengatur/mengelola keuangan secara efisien sedangkan pengendalian merupakan kegiatan untuk mengevaluasi apakah pengelolaan keuangan sudah sesuai dengan yang direncanakan/ dianggarkan.

Perkembangan pengguna internet dan pertumbuhan e-commerce tersebut di atas khususnya di Indonesia mempengaruhi semua bidang dan membuat perubahan yang signifikan pada gaya hidup masyarakat Indonesia. 
Pergeseran belanja masyarakat akan lebih banyak dihabiskan untuk kepentingan gaya hidup, liburan, wisata, kuliner dan gadget. Dukungan teknologi ini secara tidak disadari menimbulkan pergeseran gaya hidup pada masyarakat Indonesia khususnya generasi $\mathrm{Y}$ atau generasi milenial ini. Generasi unik yang menjadi sorotan dan banyak dibicarakan dan juga diangkat ke berbagai artikel dan jurnal (Wulandari \& Nugraheni, 2020).

Berdasarkan hasil observasi peneliti, peneliti melihat adanya fenomena gaya hidup modern dikalangan karyawan yang membuat karyawan tersebut cenderung mengikuti perkembangan zaman. Dengan kondisi keuangan yang memadai untuk sebisa mungkin karyawan tersebut mengikuti arus modernitas yaitu melalui penggunaan barang-barang berkelas, gaya berpakaian, dandanan yang sesuai dengan style saat ini agar tercipta suatu image sebagai karyawan yang berkelas. Hal itu disebabkan karena kurangnya tingkat pengetahuan karyawan mengenai pengelolaan keuangan yang lebih efisien.

Faktor-faktor utama pembentuk gaya hidup dapat dibagi menjadi dua yaitu secara demografis dan psikografi. Faktor demografis misalnya berdasarkan tingkat pendidikan, usia, tingkat penghasilan dan jenis kelamin, sedangkan faktor psikografis lebih kompleks karena indikator penyusunanya dari karakteristik individu. Hal ini menyebabkan karyawan mengimitasi perilaku yang dilakukan oleh sekelilingnya.

\section{Literasi keuangan}

Literasi keuangan adalah kemampuan dalam memahami pro dan kontra dari suatu keputusan keuangan, pertimbangan biaya dan dengan percaya diri memutuskan apa yang harus dilakukan. Menjadi pribadi yang melek finansial bukan berarti seseorang mengetahui segala hal tentang uang melainkan melengkapi diri untuk mencari jawaban yang dibutuhkan dalam membuat keputusan keuangan yang baik. Literasi keuangan adalah kemampuan dalam memahami dan menggunakan berbagai kemampuan keuangan secara efektif, seperti manajemen keuangan pribadi, penganggaran dan investasi. Literasi keuangan merupakan fundamental dari hubungan seseorang dengan uang dan akan terus dipelajari sepanjang hayat.

Menurut survei Otoritas Jasa Keuangan (OJK) di dalam jurnal Tsalitsa (2016, hal.4) menyatakan bahwa : "Literasi keuangan adalah rangkaian proses atau aktivitas untuk meningkatkan pengetahuan (knowledge), keterampilan (skill), keyakinan (confidence) konsumen 
dan masyarakat luas sehingga mereka mampu mengelola keuangan pribadi lebih baik".

Tingkat literasi keuangan keuangan dari sudut pandang perorangan atau keluarga dapat memiliki dampak pada kemampuan untuk memiliki tabungan jangka panjang yang digunakan untuk memiliki aset (seperti tanah atau rumah), pemenuhan pendidikan tinggi dan dana hari tua (pensiun) (Aribawa, 2016). Sementara itu, Chen dan Volpe (1998) mengartikan literasi keuangan sebagai pengetahuan untuk mengelola keuangan agar bisa hidup lebih sejahtera di masa yang akan datang. Kecakapan (literacy) merupakan hal penting yang harus dimiliki untuk mencapai tujuantujuannya. Dengan demikian riset ini akan mengunakan definisi menurut (Chen \& Volpe, 1998) karena lebih menekankan pada kemampuan untuk memahami konsep dasar dari ilmu ekonomi dan keuangan, hingga bagaimana menerapkannya secara tepat. Selain itu juga, definisi menurut Chen dan Volpe (1998) memiliki 4 aspek yaitu pengetahuan umum, tabungan, asuransi dan investasi yang sesuai dengan pengelolaan keuangan pribadi.

Hampir disemua negara memberikan perhatian yang sangat besar pada peningkatan literasi keuangan masyarakat yang pada akhirnya akan meningkatkan tingkat penggunaan keuangan masyarakat. Dalam bukunya S. Soetiono \& Setiawan (2018, hal. 24) Adapun manfaat Literasi Keuangan adalah sebagai berikut :

1) Bagi Individu, Manfaatnya dapat meningkatkan pemahaman tentang produk keuangan yang ditawarkan oleh lembaga keuangan formal dan terhindar dari aktivitas investasi pada instrumen keuangan yang tidak jelas.

2) Bagi Lembaga Keuangan, Manfaatnya untuk meningkatkan kompetisi atau tingkat persaingan yang sehat antara lembaga keuangan.

3) Bagi Negara, Manfaatnya dapat mendorong pertumbuhan ekonomi, pengentasan kemiskinan, mengurangi ketimpangan pendapatan, dan meningkatkan stabilitas sistem keuangan.

\section{Gaya Hidup}

Gaya hidup acap kali diartikan melalui aktivitas seseorang, peminatan seseorang, dan opini dari personal. Dan lebih dapat digambarkan dengan perlakuan seseorang terhadap lingkungan dan sesamanya yaitu tentang cara mereka hidup, mengalokasikan uangnya, dan meluangkan waktunya (Aulianigrum \& Rochmawati, 2021).

Gaya hidup adalah menunjukkan 
bagaimana orang hidup, bagaimana membelanjakan uang nya dan bagaimana mengalokasikan waktu. Sehingga dapat disimpulkan bahwa gaya hidup adalah pola hidup seseorang yang dinyatakan dalam kegiatan, minat, dan pendapatnya dalam membelanjakan uangnya dan bagaimana mengalokasikan waktu. Gaya hidup mencerminkan pola konsumtif yang menggambarkan pilihan seseorang untuk bagaimana ia mempergunakan waktu dan uangnya. Jadi definisi di atas dapat disimpulkan bahwa gaya hidup lebih menggambarkan perilaku seseorang, yaitu bagaimana ia hidup, menggunakan uangnya dan memanfaatkan waktu yang dimilikinya (Haryanti, 2021).

Faktor-faktor yang mempengaruhi gaya hidup menurut Kotler dan Amstrong (2016:48) mengemukakan bahwa gaya hidup seseorang dapat dilihat dari perilaku yang dilakukan oleh individu seperti kegiatan-kegiatan untuk mendapatkan atau mempergunakan barang-barang dan jasa, termasuk didalamnya proses pengambilan keputusan pada penentuan kegiatankegiatan tersebut.

Menurut Amstrong bahwa faktorfaktor yang mempengaruhi gaya hidup seseorang ada 2 faktor yaitu faktor yang berasal dari dalam diri individu (internal) dan faktor yang berasal dari luar (eksternal). Faktor internal tersebut antara lain meliputi sikap, pengalaman dan pengamatan, kepribadian, konsep diri, motif, dan persepsi. Sedangkan faktor eksternal meliputi kelompok referensi, keluarga, yang berasal kelas sosial, dan kebudayaan.

\section{Menurut}

pendapat

Sunarto, indikator gaya hidup seseorang dapat dilihat dari beberapa hal beriut ini : Kegiatan (Activity), Minat (Interest), dan Opini (Opinion). Gaya hidup dianggap sebagai identitas dan pengakuan status social seseorang yang jelas terlihat dari perilakunya yang selalu mengikuti perkembangan mode sebagai bagian utama untuk pemenuhan kebutuhan hidup sehari-hari. Bahkan gaya hidup menjadi lebih penting dari kebutuhan pokok. (Pulungan, et al 2018).

Berdasarkan teori diatas penulis dapat menyimpulkan Gaya hidup adalah gambaran tingkah laku, pola hidup seseorang yang dinyatakan dalam kegiatan, minat dan pendapatnya dalam membelanjakan uangnya dan bagaimana mengalokasikan waktunya.

\section{Pengelolaan Keuangan Pribadi}

Manajemen keuangan pribadi adalah suatu hal yang perlu dikuasai semua orang agar kondisi finansialnya selalu positif dan tidak mengkhawatirkan. Saat berbicara tentang keuangan, Selain cara menghasilkan uang, yang tidak kalah 
penting yaitu cara mengatur keuangan. Anda mungkin pernah menjumpai orang dengan pekerjaan dan penghasilan terjamin namun kondisi finansialnya berantakan (komunal.co.id).

Menurut Norma Yulianti dan Meliza Silvy (2013), dalam jurnal (Yushita, 2017, hal. 22) dalam melakukan pengelolaan keuangan haruslah ada perencanaan keuangan untuk mencapai tujuan, baik tujuan jangka pendek maupun jangka panjang. Media pencapaian tujuan tersebut dapat melalui tabungan, investasi, atau pengalokasian dana. Dengan pengelolaan keuangan yang baik, maka tidak akan terjebak pada perilaku berkeinginan yang tidak terbatas.

Ketidakstabilan finansial sering diakibatkan karena ketidakmampuan seseorang dalam mengatur keuangan pribadinya. Agar tidak mengalami kesulitan finansial, kuncinya adalah mampu memaksimalkan kemampuan dalam mengaturnya. Sebesar apapun gaji yang diperoleh setiap bulan, jika tidak dibarengi dengan pengelolaan yang baik, maka kemandirian finansial di masa depan akan sulit diwujudkan.

Berbagai manfaat yang didapatkan saat mengelola keuangan ini bisa semakin memotivasi diri saat sudah menerapkan kebiasaan dalam mengelola keuangan, sehingga ketika menemukan hambatan di tengah jalan bisa mengatasinya dan bisa kembali on the track in your financial plan.

Dengan demikian penulis menyimpulkan bahwa pengelolaan keuangan adalah kemampuan seseorang dalam mengatur, mengelola, merencanakan, dan menyimpan keuangannya sehari-hari. Dengan demikian penulis menyimpulkan bahwa pengelolaan keuangan adalah kemampuan seseorang dalam mengatur, mengelola, merencanakan, dan menyimpan keuangannya sehari-hari.

\section{METODE PENELITIAN Pendekatan Penelitian}

Dalam melakukan suatu penelitian sangat perlu dilakukan perencanaan penelitian agar penelitian yang dilakukan dapat berjalan dengan baik dan sistematis (Marpaung, 2022). Jenis penelitian yang digunakan dalam penelitian ini adalah penelitian kuantitatif deskriptif yaitu penelitian yang kemudian diolah dan dianalisis untuk mengambil kesimpulan, artinya penelitian yang dilakukan adalah penelitian yang menekankan analisisnya pada data-data numerik (angka) yang diolah dengan menggunakan metode penelitian ini, akan diperoleh hubungan yang signifikan antar variabel yang diteliti. 


\section{Populasi, Sampel, dan Teknik Sampel}

Populasi penelitian ini adalah karyawan PT. Mulia Boga Raya Tbk yang bekerja di Office sejumalah 70 Karyawan. Dalam penentuan jumlah sampel yang akan dipilih, penulis menggunakan tingkat kesalahan $10 \%$ dan tingkat kepercayaan 90\% karena dalam setiap penelitian tidak mungkin hasilnya sempurna 100\%, semakin besar tingkat kesalahan maka semakin sedikit ukuran sampel. Jumlah populasi yang dijadikan ukuran sampel adalah 42 karyawan. Untuk menentukan jumlah sampel, menggunakan rumus slovin.

\section{Jenis dan Sumber Data}

Dalam penelitian ini, pengumpulan data dengan menyebarkan kuesioner kepada responden. Dan biasanya para peneliti menyebarkan kuesioner yang berisi pertanyaan-pertanyaan meliputi literasi keuangan dan gaya hidup terhadap pengelolaan keuangan karyawan di PT. Mulia Boga Raya Tbk. Penggunaan kuesioner bertujuan untuk mendapatkan informasi yang dibutuhkan serta mendukung penelitian. Tingkat kesetujuan itu pada umumnya memiliki pernyataan gradasidari yang sangat positif sampai sangat negatif dan dibagi atas skor penilaian yaitu :
Tabel 1. Skala Likert

\begin{tabular}{|l|c|}
\hline \multicolumn{1}{|c|}{ Keterangan } & Skor \\
\hline Sangat Setuju (SS) & 5 \\
\hline Setuju (S) & 4 \\
\hline Kurang Setuju (KS) & 3 \\
\hline Tidak Setuju (TS) & 2 \\
\hline Sangat Tidak Setuju (STS) & 1 \\
\hline
\end{tabular}

\section{HASIL DAN PEMBAHASAN}

\section{Uji Validitas dan Reliabilitas}

Uji validitas digunakan untuk mengetahui kelayakan butir-butir dalam suatu daftar pertanyaan yang di berikan kepada responeden untuk dapat mendefinisikan suatu variabel (Marpaung, 2021).

Tujuan pengujian reliabilitas adalah untuk melihat apakah instrument penelitian merupakan instrument yang handal dan dapat dipercaya maka hasil penilitian juga dapat memiliki tingkat keterpercayaan yang tinggi.

Suatu konstruk dan variable dikatakan realibel jika memberikan nilai Cronback Alpha >0,70.

Tabel 2. Hasil Uji Validasi dan Reabilitas

\begin{tabular}{ccc} 
Variabel & $\begin{array}{c}\text { Cronbach } \\
\text { Alpha }\end{array}$ & Keterangan \\
\hline $\begin{array}{c}\text { Pengelolaan } \\
\text { Keuanga }\end{array}$ & 0,724 & $\begin{array}{l}\text { Valid dan } \\
\text { Reliabel }\end{array}$ \\
\hline $\begin{array}{c}\text { Literasi } \\
\text { Keuangan }\end{array}$ & 0,721 & $\begin{array}{l}\text { Valid dan } \\
\text { Reliabel }\end{array}$ \\
\hline Gaya Hidup & 0,925 & $\begin{array}{l}\text { Valid dan } \\
\text { Reliabel }\end{array}$ \\
\hline
\end{tabular}

Sumber : Data diolah 2022 
Hasil uji reliabilitas menunjukkan bahwa untuk indikator-indikator dari seluruh poin dan total pertanyaan dari literasi keuangan, gaya hidup, dan pengelolaan keuangan bahwa Cronbach Alpha lebih besar dari nilai Cronbach Alpha yang ditentukan yaitu lebih besar $(>0,70)$. Dapat disimpulkan bahwa keseluruhan variabel tersebut adalah reliabel.

\section{Uji Heterokedastisitas}

Heterokedastisitas adalah yang mana dalam model tidak terjadi ketidaksamaan variansi dari residual pada satu pengamatan ke pengamatan yang lain. Cara memprediksi ada atau tidaknya heterokedastisitas pada suatu model dapat dilihat pada uji glejser. Hasil uji heterokedastisitas yang diperoleh dalam penelitian ini bisa dilihat sebagai berikut :

\section{Hasil Uji Heterokedastisitas}

\begin{tabular}{|c|c|c|c|c|c|c|c|c|}
\hline \multicolumn{9}{|c|}{ Coefficients $^{a}$} \\
\hline \multirow[b]{2}{*}{ Model } & & \multicolumn{2}{|c|}{ Unstandardized Coefficients } & \multirow{2}{*}{$\begin{array}{c}\text { Standardized } \\
\text { Coefficients } \\
\text { Beta }\end{array}$} & \multirow[b]{2}{*}{$\mathrm{t}$} & \multirow[b]{2}{*}{ Sig. } & \multicolumn{2}{|c|}{ Collinearity Statistics } \\
\hline & & $B$ & Std. Error & & & & Tolerance & VIF \\
\hline \multirow[t]{3}{*}{1} & (Constant) & 1,528 & 5,172 & &, 296 &, 769 & & \\
\hline & LITERASI KEUANGAN &,- 017 &, 101 &,- 033 &,- 170 &, 866 &, 670 & 1,493 \\
\hline & GAYA HIDUP &, 041 &, 152 &, 053 & 273 & ,787 & 670 & 1,493 \\
\hline
\end{tabular}

Sumber : Data diolah 2022

\section{Analisis Regresi Linear Berganda}

Berdasarkan dari hasil uji heterokedasitas dengan menggunakan uji glejser nilai signifikansi (sig) untuk variable X1 literasi keuangan sebesar $0,866>0,05$, variable $\mathrm{X} 2$ gaya hidup sebesar 0,787 > 0,05. Bisa disimpulkan terbebas dari gejala heterokedasitas.
Hasil pengelolaan menggunakan data SPSS pada multiple regression analysis tentang Literasi Keuangan (X1) dan Gaya Hidup (X2) terhadap Pengelolaan Keuangan (Y) pada karyawan PT. Mulia Boga Raya Tbk regresi maka dapat dilihat tabel berikut:

\section{Hasil Uji Regresi Berganda}

\begin{tabular}{|c|c|c|c|c|c|c|}
\hline \multicolumn{7}{|c|}{ Coefficients $^{a}$} \\
\hline \multirow[b]{2}{*}{ Model } & & \multicolumn{2}{|c|}{ Unstandardized Coefficients } & \multirow{2}{*}{$\begin{array}{c}\text { Standardized } \\
\text { Coefficients } \\
\text { Beta }\end{array}$} & \multirow[b]{2}{*}{$t$} & \multirow[b]{2}{*}{ Sig. } \\
\hline & & $\mathrm{B}$ & Std. Error & & & \\
\hline \multirow[t]{3}{*}{1} & (Constant) &, 482 & 8,324 & &, 058 &, 954 \\
\hline & LITERASI KEUANGAN & 623 & 163 &, 542 & 3,825 &, 000 \\
\hline & GAYA HIDUP & 372 & 245 & 215 & 1,518 & 137 \\
\hline
\end{tabular}

Sumber : Data diolah 2022 
Berdasarkan data tabel coefficients diatas pada kolom Unstandardized Coefficients dapat dilihat persamaan regresi ganda untuk dua predictor pada variable Literasi Keuangan (X1) dan Gaya Hidup (X2) adalah:

$$
\mathbf{Y}=\boldsymbol{\beta}+\boldsymbol{\beta}_{1} \mathbf{x}_{1}+\boldsymbol{\beta}_{2} \mathbf{x}_{2}+\varepsilon
$$

Maka diperoleh nilai ;

$$
\mathrm{Y}=0,482+0,623 \mathrm{X} 1+0,372 \mathrm{X} 2+\boldsymbol{\varepsilon}
$$

Perolehan ini dari persamaan diatas menunjukkan bahwa semua variabel bebas Literasi Keuangan (X1) dan Gaya Hidup (X2) memiliki nilai koefisien yang positif,

\section{Pembahasan Hasil Penelitian}

Berdasarkan hasil uji statistik dapat disimpulkan sebagai berikut :
Pengaruh Literasi Keuangan (X1) terhadap Pengelolaan Keuangan (Y)

Literasi keuangan berpengaruh terhadap pengelolaan keuangan pada karyawan PT. Mulia Boga Raya Tbk, artinya tingkat literasi keuangan karyawan PT. Mulia Boga Raya Tbk di office dikategorikan signifikan.. Hal ini dapat dilihat dari signifikan $t_{\text {hitung }}$ sebesar 3,825 sedangkan $t_{\text {table }} 2,022$ dan mempunyai angka signifikan sebesar $0,00<0,05$ dengan arti bahwa jika $t_{\text {hitung }} \leq \mathrm{t}_{\text {table }}$ berarti $\mathrm{H}_{0}$ diterima hal ini menunjukkan ada pengaruh yang signifikan antara variabel literasi keuangan (X1) terhadap pengelolaan keuangan (Y) pada karyawan di office PT. Mulia Boga Raya Tbk.

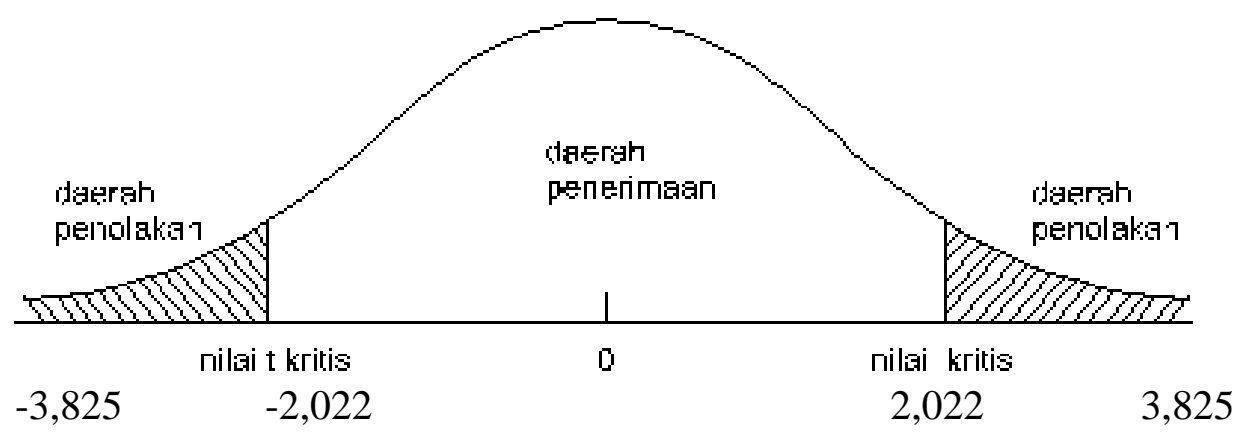

Gambar 1. Kriteria Pengujian Uji t (Hipotesis 1)

Berdasarkan hasil tersebut dapat disimpulkan bahwa secara parsial literasi keuangan berpengaruh langsung terhadap pengelolaan keuangan Karyawan Office PT. Mulia Boga Raya Tbk. Hal ini dapat dijelaskan bahwa seseorang yang memiliki literasi keuangan yang rendah, sedang, maupun tinggi bukan berarti menjadi faktor yang dapat mempengaruhi perilaku untuk mengambil keputusan yang tepat dalam mengelola keuangan.

Pengaruh Gaya Hidup terhadap Pengelolaan Keuangan 
Gaya hidup tidak berpengaruh terhadap pengelolaan keuangan pada Karyawan Office PT. Mulia Boga Raya Tbk. Hal ini dapat dilihat dari signifikan $t$ pengaruh gaya hidup terhadap pengelolaan keuangan diperoleh berdasarkan hasil pengujian gambar 4.3 secara parsial pengaruh Gaya Hidup (X2) terhadap Pengelolaan Keuangan (Y) diperoleh $t_{\text {hitung }}$ sebesar 1,518 sedangkan $t_{\text {table }} 2,022$ dan mempunyai angka signifikan sebesar $0,137>0,05$ dengan arti bahwa jika $t_{\text {hitung }} \geq t_{\text {table }}$ berarti $\mathrm{H}_{0}$ tidak diterima hal ini menunjukkan bahwa tidak ada pengaruh yang signifikan antara variabel literasi keuangan (X1) terhadap pengelolaan keuangan (Y) pada karyawan di office PT. Mulia Boga Raya Tbk.

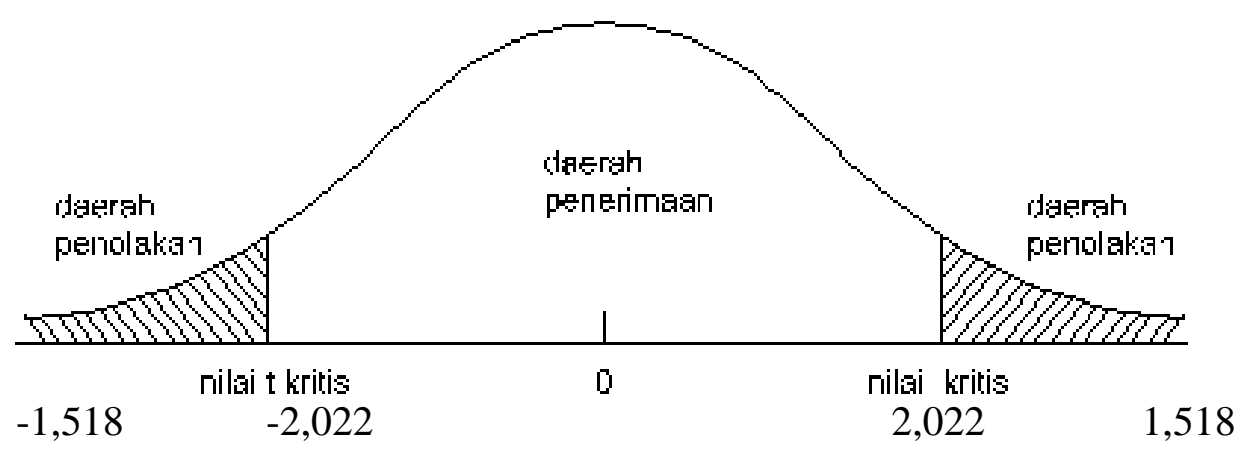

Gambar2 : Kriteria Pengujian Uji t (Hipotesis 2)

Berdasarkan hasil tersebut dapat disimpulkan bahwa secara parsial gaya hidup tidak berpengaruh terhadap pengelolaan keuangan Karyawan Office PT. Mulia Boga Raya Tbk.

\section{Pengaruh Literasi Keuangan dan Gaya} Hidup terhadap Pengelolaan Keuangan

Literasi keuangan dan gaya hidup berpengaruh terhadap pengelolaan keuangan pada Karyawan Office PT. Mulia Boga Raya Tbk, artinya semakin baik tingkat literasi keuangan karyawan, maka semakin tinggi pengelolaan keuangan pada Karyawan Office PT. Mulia Boga Raya Tbk hal ini dilihat signifikan $\mathrm{F}$ pengaruh literasi keuangan dan gaya hidup terhadap pengeloaan keuangan Fhitung sebesar 17,619 nilai $F_{\text {table }}$ sebesar 3,23 dengan tingkat signifikan 0,001. Berdasarkan nilai kurva tersebut dapat dipahami bahwa terdapat pengaruh antara variabel literasi keuangan (X1) dan Gaya Hidup (X2) secara bersama-sama terhadap Pengelolaan Keuangan (Y).

\section{Kriteria Pengujian Uji F (Hipotesis 3)}

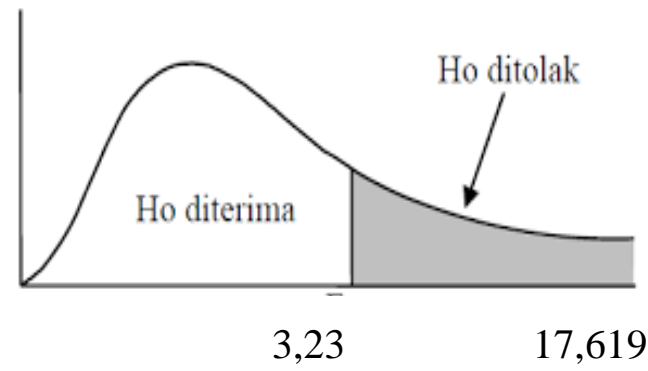

Gambar 3. Kriteria Pengujian Uji F (Hipotesis 3) 
Sehingga dapat disimpulkan bahwa literasi keuangan berpengaruh terhadap pengelolaan keuangan Karyawan Office PT. Mulia Boga Raya Tbk dan gaya hidup tidak berpengaruh terhadap pengelolaan keuangan Karyawan Office PT. Mulia Boga Raya Tbk.

\section{KESIMPULAN}

Hasil analisis yang dibahas sebelumnya, maka dapat di tarik kesimpulan sebagai berikut :

1. Literasi keuangan berpengaruh terhadap pengelolaan keuangan pada karyawan PT. Mulia Boga Raya Tbk, artinya tingkat literasi keuangan karyawan PT. Mulia Boga Raya Tbk di office dikategorikan signifikan.. Hal ini dapat dilihat dari signifikan thitung sebesar 3,825 sedangkan ttable 2,022 dan mempunyai angka signifikan sebesar $0,00<0,05$ dengan arti bahwa jika thitung $\leq$ ttable berarti $\mathrm{H} 0$ diterima.

2. Gaya hidup tidak berpengaruh terhadap pengelolaan keuangan pada Karyawan Office PT. Mulia Boga Raya Tbk. Hal ini dapat dilihat dari signifikan $\mathrm{t}$ pengaruh gaya hidup terhadap pengelolaan keuangan diperoleh berdasarkan hasil pengujian gambar 4.3 secara parsial pengaruh Gaya Hidup (X2) terhadap Pengelolaan Keuangan (Y) diperoleh thitung sebesar 1,518 sedangkan ttable 2,022 dan mempunyai angka signifikan sebesar $0,137>0,05$ dengan arti bahwa jika thitung $\geq$ ttable berarti H0 tidak diterima.

3. Literasi keuangan dan gaya hidup berpengaruh terhadap pengelolaan keuangan pada Karyawan Office PT. Mulia Boga Raya Tbk, artinya semakin baik tingkat literasi keuangan karyawan, maka semakin tinggi pengelolaan keuangan pada Karyawan Office PT. Mulia Boga Raya Tbk hal ini dilihat signifikan $\mathrm{F}$ pengaruh literasi keuangan dan gaya hidup terhadap pengeloaan keuangan Fhitung sebesar 17,619 nilai Ftable sebesar 3,23 dengan tingkat signifikan 0,001 .

\section{Saran}

Ada beberapa saran yang perlu dipertimbangkan dalam penelitian tentang literasi keuangan, gaya hidup dan pengelolaan keuangan, diantaranya adalah sebagai berikut :

1. Penelitian berikutnya sangat diharapkan karena penelitian mengenai literasi keuangan, gaya hidup terhadap pengelolaan keuangan karyawan masih sangat sedikit di Indonesia. Penelitian selanjutnya bisa menggunakan sample dari berbagai karyawan perusahaan di indonesia dan juga menambah variabel untuk mengukur literasi keuangan, gaya 
hidup dan pengelolaan keuangan.

2. Karyawan disarankan untuk selalu belajar dan peka terhadap informasi mengenai keuangan agar memiliki financial literacy yang cukup tinggi sehingga dapat terhindar dari masalah keuangan dan literasi keuangan di Indonesia dapat meningkat.

\section{REFERENCES}

Alamanda, Y. 2018. "Pengaruh Harga Diri dan Gaya Hidup Terhadap Perilaku Konsumtif." Jurnal Ilmiah Psikologi 273-279.

Astuti, R., Tanjung, H., \& Puteri, L. P. (2019). The Effect of Financial Literation on Online Shopping Interest in Millennials. International Journal Of Accounting \& Finance in Asia Pasific (IJAFAP), 5(1), 41-45.

Atkinson, A., \& Messy, F. (2018).

Literasi Keuangan. In Literasi dan Inklusi Keuangan Indonesia (p. 7). Rajawali pers.

Aulianingrum, R. D. (2021). Pengaruh Literasi Keuangan, Status Sosial Ekonomi Orang Tua, dan Gaya Hidup Teerhadap Pengelolaan Keuangan Pribadi Siswa. Jurnal Pendidikan Ekonomi; Jurnal Ilmiah Ilmu Pendidikan, Ilmu Ekonomi, Dan Ilmu Sosial, 15(2), 198-206.

Chen, H., \& Volpe, R. P. (1998). An Analysis of Personal Financial Literacy Among College Students. Financial Service Review, 7(2), 107128

Ferrinadewi, E. (2016). Pengaruh NilaiNilai Hedonis dan Konsep DiriTerhadap Keputusan Pembelian dan Dampaknya Pada Loyalitas Merekdi Surabaya ( studi pada pembelian barang mewah ). EJournal Manajemen Kinerja, 2(2), $1-11$.

Gunawan, A., Pulungan, D. R., \& Koto, M. (2019). Tingkat Literasi Keuangan Dosen Fakultas Ekonomi dan Bisnis Universitas Muhammadiyah Sumatera Utara. Seminar Nasional \& Call For Paper Seminar Bisnis Magister Manajemen (SAMBIS-2019), 1(2685-1474), 1-9.

Marpaung, N. N. (2021). Relationship of Brand Ambassadors with Interest to Buy: Lazada e-Commerce Study. 7(2), 341-352.

Marpaung, N. N. (2022). Dinamika Kinerja Karyawan PT Adia Mirsi Mindo ( AMM ) Jakarta; Analisis Pengaruh Motivasi Kerja. 7(1).

Marpaung, N. N. (2022). Dinamika Kinerja Karyawan PT Adia Mirsi Mindo ( AMM ) Jakarta; Analisis Pengaruh Motivasi Kerja. 7(1).

Mahaeni, N. K. K. N., Jayawarsa, A. A. K., \& Bagiada, K. (2020). FaktorFaktor Yang Mempengaruhi Literasi Keuangan Dalam Penggunaan Produk Dan Jasa Lembaga Keuangan (Studi pada Mahasiswa Aktif Semester V Fakultas Ekonomi dan Bisnis Universitas Warmadewa). Warmadewa Economic Development Journal (WEDJ), 3(2), 59-64.

Masturi, H., Hasanawi, A., \& Hasanawi, A. (2021). Jurnal Inovasi Penelitian. Jurnal Inovasi Penelitian, 1-208.

Pulungan, D. R., \& Febriaty, H. (2018). Pengaruh Gaya Hidup Dan Literasi Keuangan Terhadap Perilaku Konsumtif Mahasiswa. Jurnal Riset Sains Manajemen, 2(3), 1 -8, 103110.

Purnama, E. D., \& Simarmata, F. E. (2021). EFEK LIFESTYLE 


\section{DALAM}

PENGARUH

MEMODERASI

KEUANGAN

PENGETAHUAN

KEUANGAN

DAN LITERASI

PERENCANAAN KEUANGAN.

Jurnal Inovasi Penelitian, 1(10), 1208.

Putri, N. A., \& Lestari, D. (2019).

Pengaruh Gaya Hidup dan Literasi

Keuangan Terhadap Pengelolaan

Keuangan Tenaga Kerja Muda di Jakarta. Jurnal Riset Akuntansi dan Keuangan, 37-40.

Putri, N. A., \& Lestari, D. (2019). Pengaruh Gaya Hidup dan Literasi Keuangan Terhadap Pengelolaan Keuangan Tenaga Kerja Muda di Jakarta. AKURASI:Jurnal Riset Akuntansi Dan Keuangan, 1(1), 36.

Ramaiya R. 2019. Emerging markets are money savvy and ready for changed 'the future of money' research.https://www.luno.com/bl og/en/post/emerging-markets-aremoney-savvy-and-ready-forchange-says-luno-the-future-ofmoney-research

Remund, D. L. (2010). Financial literacy explicated: the case for a clearer definition in an increasingly complex economy. Journal of Consumer Affairs, 44(2), 276-295.

Resma, M., Sigo, N., \& Hariani, L. S. (2018). Pengaruh Literasi Keuangan Kecerdasan Spiritual. Jurnal Riset Pendidikan Ekonomi (JRPE), 3(1), 1-8.

Marpaung, N. N. (2021). Relationship of Brand Ambassadors with Interest to Buy : Lazada e-Commerce Study. 7(2), 341-352.

Marpaung, N. N. (2022). Dinamika Kinerja Karyawan PT Adia Mirsi Mindo ( AMM) Jakarta ; Analisis
Pengaruh Motivasi Kerja. 7(1).

Setyawati, I., \& Suroso, S. (2016). Sharia Financial Literacy And Effect On Social Economic Factors Survey On Lecturer In Indonesia. International Journal of Scientific \& Technology Research, 4(8), 92-102.

SHOLEH, B. (2019). Pengaruh Literasi Keuangan Terhadap Perilaku Keuangan Mahasiswa Program Studi Pendidikan Ekonomi Universitas Pamulang. Jurnal Pendidikan, Ekonomi, Dan Bisnis, 4(2), 57. https://doi.org/10.32493/pekobis.v4i 2.p57-67.4306

Marpaung, N. N. (2021). Relationship of Brand Ambassadors with Interest to Buy: Lazada e-Commerce Study. 7(2), 341-352.

Marpaung, N. N. (2022). Dinamika Kinerja Karyawan PT Adia Mirsi Mindo ( AMM) Jakarta ; Analisis Pengaruh Motivasi Kerja. 7(1).

Suryanto, S., \& Rasmini, M. (2018). Analisis Literasi Keuangan Dan Faktor-Faktor Yang Mempengaruhinya (Survey pada Pelaku Usaha Mikro, Kecil, Dan Menengah di Kota Bandung). Jurnal Ilmu Politik Dan Komunikasi, 8(2). https://doi.org/10.34010/jipsi.v8i2.13 36

Wahyuningsih, W., \& Fatmawati, I. (2016). The influence of Hedonistic Lifestyle, Shopping Addiction, Fashion Involvement on Global Brand Impulse Buying. 7(2), 278300. 